\author{
Wimon Phuntuwate $\cdot$ Chuthamanee Suthisisang \\ Banhan Koanantakul · Michael I Mackness \\ Bharti Mackness
}

\title{
Paraoxonase 1 status in the Thai population
}

Received: 18 April 2005/ Accepted: 19 April 2005 / Published online: 28 May 2005

(C) The Japan Society of Human Genetics and Springer-Verlag 2005

\begin{abstract}
Human serum paraoxonase 1 (PON1), a highdensity lipoprotein (HDL)-associated enzyme, has been shown to reduce the oxidation of low-density lipoprotein (LDL) and HDL by degrading lipid peroxides. This property of PON1 accounts for its ability to protect against atherosclerosis. In this study, we identified four polymorphisms in both the coding (L55M and Q192R) and regulatory regions (T-108C and G-909C) of the human PON1 gene in 202 healthy Thai individuals and investigated the influence of these polymorphisms on serum PON1 activity towards three substrates, namely, paraoxon, phenylacetate and diazoxon. The PON1 L55M, Q192R and G-909C polymorphisms significantly affected the variation in serum PON1 activity towards paraoxon. Serum PON1 activity towards paraoxon was significantly different among the genotype groups, as follows: $55 \mathrm{LL}>55 \mathrm{LM} / 55 \mathrm{MM}, 192 \mathrm{RR}>192 \mathrm{QR}>$ 192QQ and $-909 \mathrm{CC}>-909 \mathrm{CG}>-909 \mathrm{GG}$. The PON1 Q192R and G-909C polymorphisms also influenced the variation in serum PON1 activity towards diazoxon but in the opposite direction to the activity towards paraoxon. Only the PON1 L55M polymorphism was associated with significant variation in serum PON1 activity towards phenylacetate while the PON1 T-108C polymorphism had no significant effect on serum PON1 activity towards any substrate. We also found linkage disequilibrium among the polymorphic sites,
\end{abstract}

\footnotetext{
W. Phuntuwate $\cdot$ C. Suthisisang $(\bowtie)$

Department of Pharmacology, Faculty of Pharmacy,

Mahidol University, Sri Ayudhaya Road,

10400 Bangkok, Thailand

E-mail: pycst@mahidol.ac.th

Tel.: + 44-662-6448678

Fax: + 44-662-2474696

B. Koanantakul

Cardiac and Preventive Center, Bhumibol Adulyadej Hospital, Bangkok, Thailand
}

M. I Mackness · B. Mackness

Manchester Royal Infirmary,

University Department of Medicine, Oxford Road,

Manchester, M13 9WL, UK including Q192R versus L55M, Q192R versus T-108C and Q192R versus G-909C. Serum PON1 activity towards both paraoxon and phenylacetate, but not diazoxon, was positively correlated with HDL cholesterol (HDL-C) and apo AI concentrations. None of the PON1 polymorphisms significantly affected serum lipid, lipoprotein or apolipoprotein concentrations. Our findings suggest that the physiological relevance of the PON1 polymorphisms is that they are associated with significant differences in serum PON1 activity, and the impact of PON1 polymorphisms on this activity is substrate-dependent.

Keywords Paraoxonase1 Polymorphisms ·

Lipoproteins $\cdot$ Paraoxon $\cdot$ Phenylacetate $\cdot$ Diazoxon

\section{Introduction}

Paraoxonase 1 (PON1) is a calcium-dependent highdensity lipoprotein (HDL)-associated esterase that is exclusively bound to the apolipoprotein AI-containing HDL fraction in serum (Blatter et al. 1993). In vitro studies have shown that PON1 inhibits the copper-induced oxidation of low-density lipoprotein (LDL) and HDL and prevents lipid peroxide accumulation on LDL (Mackness et al. 1991a, 1993, 1998b; Aviram et al. 1998a, 1998b; Cao et al. 1999). In addition, PON1 is able to destroy oxidised phospholipids in modified LDL, therefore reversing the pro-inflammatory actions of LDL (Watson et al. 1995). The PON1 also has the ability to hydrolyse lipid peroxides within human carotid and coronary atheromatous lesions ex vivo (Aviram et al. 2000). Thus, PON1 may alter the risk for atherosclerosis by cleansing LDL of oxidised lipids and by preserving the ability of HDL to induce cellular cholesterol efflux from macrophages in vivo (Aviram 1999).

The PON1 activity is genetically determined and has marked inter-individual variation (Adkin et al. 1993; Humbert et al. 1993). This variation is partly due to 
PON1 gene polymorphisms although nutritional, pharmacological and environmental factors also affect PON1 levels (Sutherland et al. 1999; Paragh et al. 2000; Balogh et al. 2001). The PON1 gene has two major coding region polymorphisms due to amino acid substitutions at position 55 (leucine to methionine; $\mathrm{L} / \mathrm{M}$ ) and at position 192 (glutamine to arginine; Q/R) (Adkin et al. 1993; Humbert et al. 1993). The PON1 Q192R polymorphism has been shown to be responsible for the substratedependent difference in the kinetics of hydrolysis by each PON1 $_{192}$ isoform (Adkin et al. 1993; Humbert et al. 1993). The $\mathrm{R}$ alloenzyme hydrolyses paraoxon more rapidly than the $\mathrm{Q}$ alloenzyme while the $\mathrm{Q}$ alloenzyme hydrolyses diazoxon, soman and sarin more rapidly than the R alloenzyme ( $\mathrm{Li}$ et al. 2000; Davies et al. 1996). Of the PON1 192 alloenzymes, the Q alloenzyme has proved to be more efficient in protecting LDL from oxidation (Aviram et al. 1998b; Mackness et al. 1997a, 1997b). The PON1 L55M polymorphism has not been demonstrated to affect the relative rates of hydrolysis of different substrates (Adkin et al. 1993; Humbert et al. 1993). However, the $\mathrm{M}$ allele is associated with lower PON1 activity, PON1 protein and PON1 mRNA levels (Blatter et al. 1997; Leviev et al. 1997; Mackness et al. 1998a; Brophy et al. 2000).

The genetic polymorphisms of the PON1 gene have been suggested to be independent risk factors for coronary heart disease (CHD) (Serrato and Marian 1995; Sanghera et al. 1997; Zama et al. 1997; Odawara et al. 1997). Both the 55LL and 192RR genotypes have been shown to be associated with increased susceptibility to CHD in some studies. However, this association was not confirmed in other studies (Ombres et al. 1998; Sanghera et al. 1998; Cao et al. 1998; Herrmann et al. 1996) or in a large meta-analysis (Wheeler et al. 2004). In addition, low serum PON1 activity has been reported in several diseases, which are associated with accelerated atherosclerosis, including CHD, diabetes mellitus, hypercholesterolaemia and chronic renal failure (Mackness et al. 1991b; Abbott et al. 1995; Paragh et al. 1998; Ikeda et al. 1998; Datoine et al. 1998). More recently, the PON1 activity phenotype has been shown to be a better predictor of CHD than that of PONI genotypes (Jarvik et al. 2000). Low PON1 activity has recently been shown to be an independent risk factor for CHD in the Caerphilly prospective study (Mackness et al. 2003).

Recent studies have reported that PON1 polymorphisms are also found in the regulatory region and have a functional effect on PON1 expression. These polymorphisms are at position -108 ( $\mathrm{T}$ or $\mathrm{C}),-162$ (A or $\mathrm{G})$ and -909 ( $\mathrm{G}$ or $\mathrm{C}$ ) where the base immediately before the start codon is numbered as "-1" (Brophy et al. 2001; Suehiro et al. 2000; Leviev and James 2000). In addition, the three regulatory and the two coding polymorphisms all show significant linkage disequilibrium (LD) to each other (Brophy et al. 2001).

Based on the hypothesis that PON1 has a protective function against CHD development, the influence of PON1 activity might be of major importance for the efficacy of its protective function. The aim of this study was to determine PON1 gene polymorphisms in both the coding region (L55M and Q192R) and regulatory region (T-108C and G-909C) and to investigate the association of these polymorphisms with PON1 activity and lipoprotein profiles in a Thai population.

\section{Subjects and methods}

\section{Study population}

Eligible subjects were recruited from subjects who attended for a routine medical check at the Division of Preventive Medicine, Royal Thai Air Force, between November 2002 and January 2003. They were defined as healthy by physical examination (weight, height and blood pressure measurements, chest X-ray, respiratory and eye examination) and laboratory tests [complete blood count, blood urea nitrogen, creatinine, uric acid, fasting blood glucose, liver function tests, total cholesterol, triglyceride and high-density lipoprotein cholesterol (HDL-C)]. Subjects with hypertension, diabetes mellitus, cardiovascular diseases, renal or hepatic diseases, inflammation, injury or trauma in the previous month, who smoked or were alcohol or drug abusers were excluded from the study. A questionnaire was used to collect family and medical history and smoking and alcohol habits from the subjects. Data collection included weight, height, waist and hip circumference, systolic and diastolic blood pressure (SBP and DBP) measurements using standard methods. Body mass index (BMI) was calculated as body weight (kilograms)/height (metres) $^{2}$. Waist-hip ratio (WHR) was calculated as waist circumference (centimetres)/hip circumference (centimetres). This study was approved by the ethics committee of Bhumibol Adulyadej Hospital, Royal Thai Air Force, and informed consent was obtained from all subjects after full explanation of the purpose of the study.

\section{Blood sampling}

Venous blood was collected from all subjects after a 12-h fast. Serum and EDTA plasma were prepared by lowspeed centrifugation. White cells were removed as the buffy coat of the EDTA-plasma tube for genomic DNA extraction. Serum, plasma and buffy coat were kept at $-80^{\circ} \mathrm{C}$ before analysis.

\section{Determination of lipids, lipoproteins} and apolipoproteins

Total serum cholesterol and direct HDL-C were determined by the CHOD-PAP method (ABX Diagnostics, Shefford, UK). Serum triglycerides were determined by the GPO-PAP method (ABX Diagnostics). The LDLcholesterol (LDL-C) was calculated by the Friedewald formula in samples with triglycerides less than 
$4.51 \mathrm{mmol} / 1 \quad(400 \mathrm{mg} / \mathrm{dl})$. Serum lipoprotein (a) and plasma oxidised LDL were determined by commercially available enzyme-linked immunosorbent assays (ELISA) (Mercodia, Uppsala, Sweden). Serum apo AI and apo B were determined by immunoturbidimetric techniques (ABX Diagnostics).

\section{Determination of PON1 activity}

The PON1 activity towards paraoxon was determined by adding $25 \mu \mathrm{l}$ serum to $0.5 \mathrm{ml}$ Tris- $\mathrm{HCl}$ buffer (100 mM, pH 8.0) containing $2 \mathrm{mM} \mathrm{CaCl}_{2}$ and $5.5 \mathrm{mM}$ paraoxon $(\mathrm{O}, \mathrm{O}$ diethyl-O-p-nitrophenylphosphate; Sigma, D9286). The rate of generation of $p$-nitrophenol was determined at $25^{\circ} \mathrm{C}$ with the use of a continuously recording spectrophotometer at $405 \mathrm{~nm}$ (Beckman Du68). PON1 activity was assessed by use of phenylacetate as substrate by adding $2.5 \mu \mathrm{l}$ serum to $0.9 \mathrm{ml}$ of the same buffer as above and $0.1 \mathrm{ml}$ of $13.62 \mathrm{mM}$ phenylacetate (Sigma, P2396). The increase in absorbance at $270 \mathrm{~nm}$ was recorded with the same spectrophotometer. The PON1 diazoxon (diazinon-O-analog) hydrolysis rate was also measured spectrophotometrically by adding $5 \mu \mathrm{l}$ serum to $1 \mathrm{ml}$ Tris- $\mathrm{HCl}$ buffer $(100 \mathrm{mM}, \mathrm{pH} 8.0$ containing $2 \mathrm{M} \mathrm{NaCl}, 2 \mathrm{mM} \mathrm{CaCl} 2$ and $3.52 \mathrm{mM}$ diazoxon) (Chem Service, Chester, UK) and recording the increase in absorbance at $270 \mathrm{~nm}$.

\section{Determination of PON1 genotypes}

Genomic DNA was extracted from white cells by the phenol-ethanol method. All genotyping was conducted by polymerase chain reaction (PRC) amplification followed by polymorphism-specific restriction digestion and gel electrophoresis. The two PON1 coding-region (L55M and Q192R) and two PON1 regulatory-region (T-108C and G-909C) polymorphisms were determined, as described previously (Mackness et al. 1998a, 1998b; Brophy et al. 2001). Each genotype was read by two people independently.

\section{Statistical analysis}

The continuous parameters were expressed as mean \pm standard deviation (SD) if they had a normal distribution and Students' unpaired $t$ test was used for comparisons. The parameters with non-normal distributions were expressed as median (range), and the MannWhitney $U$ test was used to compare differences. The normality of the sample distribution of each continuous parameter was tested with the Kolmogorov-Smirnov test. Pearson's correlation and Spearman's correlation tests were used to test the strength of associations of parameters with normal and non-normal distributions, respectively. For the purposes of genetic analysis, as no differences in polymorphism distribution were observed, data from male and female subjects were combined. Allele frequencies were calculated by the gene-counting method. The chi-square test was used to determine the observed genotype frequencies deviated from HardyWeinberg equilibrium expectations and to evaluate the significance of the LD between each polymorphism pair. One-way ANOVA and Kruskal Wallis tests were used for comparison of normally and non-normally distributed parameters among genotypes, respectively. A $p$ value of less than 0.05 was considered statistically significant. All statistical analyses were performed by using SPSS Version 10.1 for Windows software.

\section{Results}

Demographic characteristics, lipoprotein profiles and serum PON1 activity in the study population

The demographic details of the study population are shown in Table 1. The study population had a greater proportion of men $(\operatorname{men}=156$, women $=46)$. The age range in men and in women was $20-58$ and 26-59, respectively. Compared with women, men were significantly younger and had significantly higher BMI, WHR, SBP and DBP. Fasting blood glucose did not differ significantly between men and women.

There were no significant differences in the levels of total cholesterol, LDL-C, oxidised LDL-C or apo B concentrations between men and women (Table 1). However, the levels of HDL-C, apo AI and Lp (a) were significantly higher in women. This was in contrast to triglyceride levels, which were significantly lower in women.

There were no significant differences in serum PON1 activity levels towards the three substrates between men and women although the median value for serum PON1 activity towards paraoxon and phenylacetate tended to be higher in women (Table 1).

Genotype and allele frequencies of the PON1 polymorphisms

The genotype and allele frequencies of four PONI polymorphisms are shown in Table 2. Genotypes at all positions did not deviate from Hardy-Weinberg equilibrium expectations using the chi-square test (data not shown). The 55LL genotype was the most common genotype found in the population $(91.1 \%)$ whereas the rarest genotype was the $55 \mathrm{MM}(0.5 \%)$ (Table 2$)$. The random combination of $\mathrm{Q}$ and $\mathrm{R}$ alleles at position 192 and $\mathrm{L}$ and $\mathrm{M}$ alleles at position 55 is expected to give rise to nine possible combinations. The most common genotypes were 192QQ/55LL (42.57\%) and 192QR/ $55 \mathrm{LL}(40.59 \%)$. However, no $192 \mathrm{RR} / 55 \mathrm{MM}$ carriers were observed, suggesting that this genotype combination does not exist or is very rare in this population. Similarly, the most common genotypes from the random 
Table 1 Demographic characteristics, lipoprotein profiles and PON1 activity of the study population ${ }^{\mathrm{a}} . B M I$ body mass index, $W H R$ waisthip ratio, $H D L-C$ high-density lipoprotein cholesterol, $L D L-C$ low-density lipoprotein cholesterol, $L p(a)$ serum lipoprotein (a)

${ }^{\text {a }}$ Values are shown as mean \pm SD and values of $p$ are obtained by Student unpaired $t$ test

$\mathrm{b}$ Values are shown as median (range), and values of $p$ are obtained by Mann-Whitney $U$ test

$* p<0.05 ; * * p<0.01 ; * * * p$ $<0.001$ : significant differences between results for men and women

Table 2 Genotype and allele frequencies of the $P O N 1$ polymorphisms in the study population

\begin{tabular}{|c|c|c|c|}
\hline Parameter & Men & Women & Total \\
\hline Number & 156 & 46 & 202 \\
\hline Age (years) & $34.6 \pm 9.7$ & $43.3 \pm 7.6^{* * *}$ & $36.6 \pm 9.9$ \\
\hline BMI $\left(\mathrm{kg} / \mathrm{m}^{2}\right)$ & $22.8 \pm 2.5$ & $21.9 \pm 2.5^{*}$ & $22.6 \pm 2.5$ \\
\hline WHR & $0.80 \pm 0.05$ & $0.73 \pm 0.04 * *$ & $0.78 \pm 0.05^{*}$ \\
\hline Systolic blood pressure (mmHg) & $123.8 \pm 9.5$ & $118.3 \pm 12.5^{* *}$ & $122.6 \pm 10.5$ \\
\hline Diastolic blood pressure (mmHg) & $72.2 \pm 8.4$ & $68.5 \pm 9.1^{*}$ & $71.4 \pm 8.7$ \\
\hline Fasting blood glucose $(\mathrm{mmol} / \mathrm{l})$ & $4.9 \pm 0.5$ & $4.9 \pm 0.4$ & $4.9 \pm 0.5$ \\
\hline Total cholesterol $(\mathrm{mmol} / \mathrm{l})$ & $5.67 \pm 0.95$ & $5.68 \pm 0.87$ & $5.68 \pm 0.93$ \\
\hline Triglycerides $(\mathrm{mmol} / \mathrm{l})^{\mathrm{b}}$ & $0.92(0.34-6.04)$ & $0.74(0.41-1.95)^{*}$ & $0.86(0.34-6.04)$ \\
\hline $\mathrm{HDL}-\mathrm{C}(\mathrm{mmol} / \mathrm{l})$ & $1.36 \pm 0.27$ & $1.55 \pm 0.25^{* *}$ & $1.40 \pm 0.28 *$ \\
\hline LDL-C $(\mathrm{mmol} / \mathrm{l})$ & $3.85 \pm 0.88$ & $3.74 \pm 0.81$ & $3.81 \pm 0.87$ \\
\hline $\operatorname{Lp~(a)~}(\mathrm{mg} / \mathrm{dl})^{\mathrm{b}}$ & $13.84(0.65-80.07)$ & $20.70(2.39-62.56)^{*}$ & $14.86(0.65-80.07)$ \\
\hline Oxidised LDL (U/1) & $39.12 \pm 13.71$ & $38.52 \pm 13.00$ & $39.04 \pm 13.51$ \\
\hline Apo AI $(g / 1)$ & $1.34 \pm 0.19$ & $1.43 \pm 0.16^{* *}$ & $1.37 \pm 0.19$ \\
\hline Apo B $(\mathrm{g} / \mathrm{l})$ & $1.01 \pm 0.21$ & $0.96 \pm 0.18$ & $1.00 \pm 0.21$ \\
\hline $\begin{array}{l}\text { PON1 activity towards } \\
\text { paraoxon }(\mathrm{nmol} / \mathrm{min} / \mathrm{ml})^{\mathrm{b}}\end{array}$ & $273.3(2.4-453.1)$ & $294.4(107.5-486.2)$ & $274.9(2.4-486.2)$ \\
\hline $\begin{array}{l}\text { PON1 activity towards phenylacetate } \\
(\mu \mathrm{mol} / \mathrm{min} / \mathrm{ml})^{\mathrm{b}}\end{array}$ & $74.6(36.9-103.6)$ & $76.9(26.9-110.6)$ & $75.7(26.9-110.6)$ \\
\hline $\begin{array}{l}\text { PON1 activity towards diazoxon } \\
(\mu \mathrm{mol} / \mathrm{min} / \mathrm{ml})^{\mathrm{b}}\end{array}$ & $9.9(1.2-23.4)$ & $9.3(3.9-21.4)$ & $9.8(1.2-23.4)$ \\
\hline
\end{tabular}

\begin{tabular}{lllll}
\hline \multicolumn{4}{l}{ Polymorphic site } & \\
\cline { 2 - 5 } & L55M & Q192R & T-108C & G-909C \\
\hline Genotype frequencies & LL: $91.1 \%$ & QQ: $50.0 \%$ & TT: $53.4 \%$ & CC: $55.4 \%$ \\
& LM: $8.4 \%$ & QR: $42.1 \%$ & CT: $43.1 \%$ & CG: $34.2 \%$ \\
Mllele frequencies & MM: $0.5 \%$ & RR: $7.9 \%$ & CC: $3.5 \%$ & GG: $10.4 \%$ \\
& L: 0.95 & Q: 0.71 & T: 0.75 & C: 0.73 \\
& M: 0.05 & R: 0.29 & C: 0.25 & G: 0.27 \\
\hline
\end{tabular}

combination of $\mathrm{T}$ and $\mathrm{C}$ alleles at position -108 and $\mathrm{C}$ and $\mathrm{G}$ alleles at position -909 were $-108 \mathrm{CT} /-909 \mathrm{CC}$ $(26.73 \%)$ and $-108 \mathrm{TT} /-909 \mathrm{CC}(26.24 \%)$. No $-108 \mathrm{CC} /$ $-909 \mathrm{GG}$ genotypes were observed in the population. The chi-square test showed significant LD between Q192R and L55M, Q192R and T-108C, and Q192R and G-909C ( $p<0.05$, data not shown).

Influence of the PON1 polymorphisms on serum PON1 activity and lipoprotein profiles

Table 3 shows serum PON1 activity towards the three substrates according to the different PON1 polymorphisms. There were significant variations in serum PON1 activity towards paraoxon as a function of $P O N 1$ L55M, Q192R, and G-909C polymorphisms. The 55LL, 192RR and -909CC genotypes had the highest PON1 activity towards paraoxon, whereas the 55M-allele carriers, 192QQ and -909GG genotypes had the lowest activity and the 192QR and -909CG heterozygotes having intermediate activity. Only the PON1 L55M polymorphism was associated with significant variation in serum PON1 activity towards phenylacetate. The PON1 Q192R and G-909C polymorphisms influenced diazoxon hydrolysis by PON1. In contrast to the influences on serum PON1 activity towards paraoxon, the 192RR and -909CC genotypes had the lowest serum
PON1 activity towards diazoxon, whereas the 192QQ and -909 GG genotypes had the highest activity and the 192QR and -909CG heterozygotes had intermediate activity. Interestingly, the PONI T-108C polymorphism did not significantly affect the variation in serum PON1 activity towards any substrate, although the $-108 \mathrm{CT}$ genotypes had the highest serum PON1 activity towards paraoxon and phenylacetate, and had the lowest activity towards diazoxon, this difference did not achieve statistical significance.

Amongst the PON1 192 genotypes the -909 polymorphism significantly affected the variation in paraoxon hydrolysis within the PON1 $1_{192}$ QQ genotype ( $p=$ 0.002 ) and diazoxon hydrolysis in $\mathrm{PON}_{192} \mathrm{Q}$ allele carriers $(p=0.006)$. Neither the 55 nor -108 polymorphism significantly affected variation in PON1 activity. No polymorphism affected phenylacetate hydrolysis (results not shown).

There were no significant effects of any PON1 polymorphism on the variation in lipid, lipoprotein or apolipoprotein concentrations (data not shown).

\section{Parameters influencing serum PON1 activity}

Parameters influencing serum PON1 activity towards the three substrates were analysed using stepwise multiple regression analysis (Table 4). The PON1 Q192R and G-909C polymorphisms were significant contribu- 
Table 3 PON1 activity towards the three substrates according to the PON1 polymorphisms

\begin{tabular}{|c|c|c|c|c|}
\hline PON1 activity & L55M & Q192R & $\mathrm{T}-108 \mathrm{C}$ & G-909C \\
\hline $\begin{array}{l}\text { Towards paraoxon } \\
(\mathrm{nmol} / \mathrm{min} \mathrm{mL})\end{array}$ & $\begin{array}{l}\text { LL: } 281.1(2.4-486.2) \\
\text { LM/MM: } 237.3(80.6-351.6) \\
p=0.017^{\mathrm{a}}\end{array}$ & $\begin{array}{l}\text { QQ: } 237.6(2.4-420.2) \\
\text { QR: } 308.7(173.7-441.0) \\
\text { RR: } 374.9(251.9-486.2) \\
p<0.001\end{array}$ & $\begin{array}{l}\text { TT: } 271.4(108.1-453.1) \\
\text { CT: } 291.9(2.4-486.2) \\
\text { CC: } 216.7(55.5-344.5) \\
p=0.326\end{array}$ & $\begin{array}{l}\text { CC: } 303.9(100.2-486.2) \\
\text { CG: } 241.8(2.4-449.6) \\
\text { GG: } 142.3(93.7-453.1) \\
p<0.001\end{array}$ \\
\hline $\begin{array}{l}\text { Towards phenylacetate } \\
(\mu \mathrm{mol} / \mathrm{min} \mathrm{mL})\end{array}$ & $\begin{array}{l}\text { LL: } 76.5(26.9-110.6) \\
\text { LM/MM: } 69.5(42.1-88.5) \\
p=0.034^{\mathrm{a}}\end{array}$ & $\begin{array}{l}\text { QQ: } 75.3(42.1-107.6) \\
\text { QR: } 75.6(26.9-110.6) \\
\text { RR: } 77.4(44.3-98.8) \\
p=0.433\end{array}$ & $\begin{array}{l}\text { TT: } 73.8(26.9-110.6) \\
\text { CT: } 76.9(44.3-100.3) \\
\text { CC: } 56.8(43.9-89.9) \\
p=0.072\end{array}$ & $\begin{array}{l}\text { CC: } 74.7(26.9-100.3) \\
\text { CG: } 74.81(36.9-110.6) \\
\text { GG: } 80.94(51.8-107.7) \\
p=0.109\end{array}$ \\
\hline $\begin{array}{l}\text { Towards diazoxon } \\
(\mu \mathrm{mol} / \mathrm{min} \mathrm{mL})\end{array}$ & $\begin{array}{l}\text { LL: } 10.1(3.7-23.4) \\
\text { LM/MM: } 9.0(1.2-19.1) \\
p=0.596^{\mathrm{a}}\end{array}$ & $\begin{array}{l}\text { QQ: } 11.7(1.2-23.4) \\
\text { QR: } 7.7(3.7-17.2) \\
\text { RR: } 7.4(3.9-14.3) \\
p<0.001\end{array}$ & $\begin{array}{l}\text { TT: } 10.5(4.2-21.4) \\
\text { CT: } 9.0(1.2-19.9) \\
\text { CC: } 11.1(5.9-23.4) \\
p=0.311\end{array}$ & $\begin{array}{l}\text { CC: } 7.6(1.2-23.4) \\
\text { CG: } 11.4(4.9-21.4) \\
\text { GG: } 14.6(7.1-21.3) \\
p<0.001\end{array}$ \\
\hline
\end{tabular}

Values are median (range)

Values of $p$ are obtained by Kruskal-Wallis

${ }^{\text {a }}$ Values of $p$ are obtained by Mann-Whitney $U$ Test

Table 4 Parameters influencing serum PON1 activity towards the three substrates

Stepwise multiple regression analysis of parameters influencing serum PON1 activity towards the three substrates is shown

The same independent parameters, including all four $P O N 1$ polymorphisms, HDL-C and apo AI concentrations were used as predictors of serum PON1 activity

\begin{tabular}{|c|c|c|c|}
\hline & Variation $(\%)$ & $p$-value & \\
\hline \multicolumn{4}{|c|}{ PON1 activity towards paraoxon } \\
\hline Model A parameter & Polymorphism Q192R & 27.0 & $<0.001$ \\
\hline Model B parameters: & $\begin{array}{l}\text { Polymorphism Q192R } \\
\text { Polymorphism G-909C }\end{array}$ & 32.3 & $<0.001$ \\
\hline \multicolumn{4}{|c|}{ PON1 activity towards phenylacetate } \\
\hline Model A parameter & HDL-C & 6.5 & $<0.001$ \\
\hline Model B parameters & $\begin{array}{l}\text { HDL-C } \\
\text { Polymorphism G-909C }\end{array}$ & 9.0 & $<0.001$ \\
\hline \multicolumn{4}{|c|}{ PON1 activity towards diazoxon } \\
\hline Model A parameter & Polymorphism G-909C & 22.0 & $<0.001$ \\
\hline Model B parameters & $\begin{array}{l}\text { Polymorphism G-909C } \\
\text { Polymorphism Q192R }\end{array}$ & 28.9 & $<0.001$ \\
\hline Model C parameters & $\begin{array}{l}\text { Polymorphism G-909C } \\
\text { Polymorphism Q192R } \\
\text { Apo AI }\end{array}$ & 31.9 & $<0.001$ \\
\hline
\end{tabular}

tors to serum PON1 activity towards paraoxon, accounting for $27.0 \%$ of the variation in this activity for Q192R and 32.3\% for Q192R together with G-909C. The HDL-C concentration and the PON1 G-909C polymorphism made significant contributions to variation in serum PON1 activity towards phenylacetate, accounting for $6.5 \%$ of the variation in this activity for HDL-C and 9.0\% for HDL-C together with G-909C. Finally, significant contributions were also observed for the PON1 G-909C and Q192R polymorphisms as well as apo AI concentration to variation in serum PON1 activity towards diazoxon, accounting for $22.0 \%$ of the variation in this activity for G-909C, 28.9\% for G-909C together with Q192R and 31.9\% for G-909C together with Q192R and apo AI.

\section{Discussion}

The PON1 is able to hydrolyse a variety of substrates, including paraoxon, diazoxon, and phenylacetate. As yet, all the physiological substrates of PON1 are unknown but recent studies suggest that PON1 prevents LDL oxidation by hydrolysing lipid peroxides in the lipoprotein (Watson et al. 1995; Aviram et al. 2000).
PON1 also hydrolyses homocysteine thiolactone, a proatherogenic metabolite (Ferretti et al. 2003) and PAF (Rodrigo et al. 2001). However, there has been some controversy over whether PON1 activity, as measured by synthetic substrates, will reflect the antioxidant capacity of this enzyme (Cao et al. 1999). A study from Aviram et al. indicated that the PON1 active site requirements for its protective role against LDL oxidation were not identical to those needed for its PON1 activity towards paraoxon and phenylacetate (Aviram et al. 1998a, 1998b). Although PON1 activity towards synthetic substrates and its protection against LDL oxidation do not involve exactly the same active site, these activities are still related (Aviram 1999). Serum PON1 activity towards paraoxon and phenylacetate was more positively correlated with HDL-C and apo AI concentrations than activity measured by diazoxon. This was in agreement with previous studies in which positive associations between PON1 activity towards paraoxon and HDL-C as well as apo AI were observed (Mackness et al. 1998a). Thus, it is likely that paraoxon and phenylacetate seemed to be better surrogate substrates than diazoxon for measuring PON1 activity. Jarvik et al. (2000) found that the PON1 activity towards diazoxon was more predictive of vascular disease status than was the PON1 activity 
towards paraoxon in marginal analysis. However, in the only prospective study published so far, paraoxon but not diazoxon hydrolysis was an independent risk factor for CHD events (Mackness et al. 2003).

In this study, we found that the serum PON1 activity among individuals with the same genotype differed. This finding is in agreement with the other studies that there was at least a 13-fold variation in PON1 activity among individuals with the same genotype (Humbert et al. 1993; Davies et al. 1996; Richter and Furlong 1999). It is possible that not only the serum PON1 activity is influenced by the PON1 polymorphisms but also by the other factors. In our study, we found that the serum PON1 activity towards paraoxon and phenylacetate, but not diazoxon, were positively correlated with HDL-C and apo AI concentrations. Therefore, the HDL-C and apo AI concentrations are likely to be one of several factors that account for the variation in serum PON1 activity. The results of stepwise multiple regression analysis confirmed that the HDL-C alone and apo AI together with the PON1 polymorphisms were significant contributors to the variation in serum PON1 activity towards phenylacetate and diazoxon, respectively. Additionally, the effects of environmental factors such as diet and exercise on serum PON1 activity have also been reported by several studies (Tomas et al. 2001, 2002; Sutherland et al. 1999;).

In this investigation, we found that the $\mathrm{L}$ and $\mathrm{M}$ allele frequencies for the PON1 coding-region (L55M) polymorphism were similar to those of Japanese and Chinese populations who displayed very low frequencies of the $M$ allele $(M=0.06)$ (Zama et al. 1997; Sanghera et al. 1998; Cao et al. 1998; Suehiro et al. 2000), but these results were different from those of Asian Indian and Caucasian populations $(\mathrm{M}=0.36)$ (Brophy et al. 2001; Leviev and James 2000; Ferre et al. 2002). However, differences in $\mathrm{Q}$ and $\mathrm{R}$ allele frequencies for the PON1 Q192R polymorphism between this population $(\mathrm{Q}=0.71, \mathrm{R}=0.29)$ and Japanese population $(\mathrm{Q}=0.40, \mathrm{R}=0.60)$ were observed, but were not found when compared with those of Caucasian populations $(\mathrm{Q}=0.74, \mathrm{R}=0.26$ ) (Zama et al. 1997; Brophy et al. 2001; Suehiro et al. 2000). The very low frequency of the $55 \mathrm{M}$ genotype in the Thai population was surprising, however, in a recent study of Han Chinese, no polymorphism of this site was found (Wang et al. 2003), further investigations in this area are required. The allele frequencies for PON1 regulatory-region (T-108C and G-909C) polymorphisms also differed from those observed in both Japanese and Caucasian populations (Brophy et al. 2001; Suehiro et al. 2000; Leviev and James 2000). Our data support the other previous studies that there are interpopulation differences in allele frequencies for the PON1 polymorphisms (Sanghera et al. 1998; Brophy et al. 2001; Suehiro et al. 2000; Leviev and James 2000). This may be a coincidence, or selection pressure that may have acted on these polymorphisms to maintain specific allele frequencies across different ethnic groups.
This is the first study to report the PON1 polymorphism distribution in a healthy Thai population. However, the association between the PON1 polymorphisms and diseases associated with atherosclerosis has not been studied in Thais. Nevertheless, the relationships between the PON1 polymorphisms and CHD have been reported from other countries in Asia. Sanghera et al. (1997) reported that the PON1 Q192R polymorphism was associated with CHD in Indians, but not in Chinese. The Indian CHD patients had a significantly higher frequency of the $192 \mathrm{R}$ allele than controls ( 0.43 vs. $0.33 ; p=0.014$ ). Similarly, Imai et al. (2000) also demonstrated the positive association of 192R variant with CHD in Japanese. This report was in agreement with the earlier reports in Japanese with and without (Zama et al. 1997; Odawara et al. 1997). The 192R allele frequency is relatively common in Japanese and Chinese (0.6-0.7) (Zama et al. 1997; Odawara et al. 1997) compared with Caucasians (0.3-0.4) (Ombres et al. 1998; Herrmann et al. 1996). The interracial variability in the allelic frequencies for the $P O N 1$ polymorphisms suggests that ethnicity-specific polymorphism distribution should be identified before association studies are performed. Based on the association between PON1 polymorphisms and the risk of CHD, the data of genotype and allelic frequencies of $P O N 1$ gene polymorphisms between ethnic groups may partly contribute to the risk for CHD in specific populations.

We found significant LD between Q192R and L55M, Q192R and T-108C, and Q192R and G-909C as has been reported previously (Brophy et al. 2001).

As expected, there were significant variations in serum PON1 activity as a function of PON1 polymorphisms. Significant variations in serum PON1 activity among genotypes classified by the PON1 L55M, Q192R and G909C polymorphisms were observed when paraoxon was used as substrate. Likewise, the variations in serum PON1 activity among these genotypes were also observed when diazoxon was used as substrate, except for those genotypes classified by the PON1 L55M polymorphism while no significant variation in serum PON1 activity using phenylacetate as substrate was observed among PONI genotypes, except for those genotypes classified by the PON1 L55M polymorphism. From this observation, paraoxon and diazoxon appeared to be discriminating substrates while phenylacetate appeared to be a nondiscriminating substrate with respect to the PON1 polymorphisms. The effects of PON1 L55M and Q192R polymorphisms on serum PON1 activity towards paraoxon were similar to that reported in the previous studies (Mackness et al. 1997a, 1998a). In our study, we found that only the PON1 L55M polymorphism was associated with significant variation in the serum PON1 activity towards phenylacetate. These findings indicate a complex interplay between the $P O N 1$ polymorphisms and activity towards different substrates. In contrast, other studies have shown that the L55M substitution did not affect this activity (Adkin et al. 1993; Humbert et al. 1993). Our findings contradict the results reported by Brophy et al. (2001) that individuals with $-108 \mathrm{TT}$ and $-909 \mathrm{CC}$ 
genotypes had the lowest PON1 activity towards phenylacetate while those with $-108 \mathrm{CC}$ and $-909 \mathrm{GG}$ genotypes had the highest activity. In addition, they noted that the T-108C polymorphic site appeared to have a dominant effect on PON1 expression while the G-909C polymorphic site appeared to have a minor contribution to transcriptional regulation. Furthermore, Suehiro et al. reported that individuals with the $-108 \mathrm{CC}$ genotype had about 1.2-fold higher PON1 concentration than those with $-108 \mathrm{TT}$; these differences could be ethnically based. A limitation of our study was that PON1 mass was not measured, thus the influence of $P O N 1$ polymorphisms on PON1 concentration has not been investigated. Nevertheless, a recent study showed that a higher PON1 concentration was not statistically related to CHD risk whereas PON1 activity towards paraoxon was statistically related to this risk (Mackness et al. 2003).

Stepwise multiple regression analysis indicated that in this population, both PON1 Q192R and G-909C polymorphisms were the major contributors for the variation in serum PON1 activity towards paraoxon and diazoxon.

The data presented in this study indicates that none of the PON1 polymorphisms significantly affect the variation in lipid, lipoprotein and apolipoprotein concentrations in a healthy Thai population. Our data are in agreement with those reported by some studies (Zama et al. 1997; Odawara et al. 1997; Herrmann et al. 1996) but not others (Hegele et al. 1995; Saha et al. 1991). It should be noted that the impact of the PON1 polymorphisms on lipid profiles may be variable depending on the ethnicity of the study population.

In conclusion, our data demonstrate that the physiological relevance of the PON1 polymorphisms in a Thai population is that they are associated with significant differences in serum PON1 activity, and the influence of the PON1 polymorphisms on the variation in serum PON1 activity is substrate-dependent. Additionally, not only do allele frequencies of $P O N 1$ polymorphisms vary between different ethnic populations, but also the LD patterns between the $P O N 1$ polymorphisms differ among ethnic populations. This study thus firmly establishes a genetic basis for the variation in serum PON1 activity. Finally, our study provides the first baseline data of PON1 status in the Thai population, which differs significantly from other oriental populations.

Acknowledgements We would like to thank Gp. Capt. Surasak Prongchantuk, the director of the Division of Preventive Medicine, Royal Thai Air Force, for allowing us to collect blood samples. We are grateful to Dr. Preecha Chaloeiphap for his assistance in blood collection. We wish to thank Maria Mastorikou, Mathew Wright and Yifen Liu for skillful assistance. This study was supported by a grant from the Ministry of University Affairs, Thailand.

\section{References}

Abbott CA, Mackness MI, Kumar S, Boulton AJ, Durrington PN (1995) Serum paraoxonase activity, concentration, and phenotype distribution in diabetes mellitus and its relationship to serum lipids and lipoproteins. Arterioscler Thromb Vasc Biol 15:1812-1818
Adkin S, Gan KN, Mody M, La Du BN (1993) Molecular basis for the polymorphic forms of human serum paraoxonase/arylesterase: glutamine or arginine at position 191, for the respective A or B allozymes. Am J Hum Genet 52:598-608

Aviram M (1999) Does paraoxonase play a role in susceptibility to cardiovascular disease? Mol Med Today 5:381-386

Aviram M, Billecke S, Sorenson R, Bisgaier C, Newton R, Rosenblat M, Erogul J, Hsu C, Dunlop C, La Du BN (1998a) Paraoxonase active site required for protection against LDL oxidation involves its free sulhydryl group and is different from that required for its arylesterase/paraoxonase activities: selective action of human paraoxonase allozymes Q and R. Arterioscler Thromb Vasc Biol 18:1617-1624

Aviram M, Rosenblat M, Bisgaier CL, Newton RS, PrimoParmo SL, La Du BN (1998b) Paraoxonase inhibits high density lipoprotein oxidation and preserves its functions: a possible peroxidative role for paraoxonase. J Clin Invest 101:1581-1590

Aviram M, Hardak E, Vaya J, Mahmood S, Milo S, Hoffman A, Billicke S, Draganov D, Rosenblat M (2000) Human serum paraoxonase (PON1) Q and R selectively decrease lipid peroxides in human coronary and carotid atherosclerotic lesions. PON1 esterase and peroxidase-like activities. Circulation 101:2510-2517

Balogh Z, Fulop P, Seres I, Harangi M, Katona E, Kovacs P, Kosztaczky B, Paragh G (2001) Effect of simvastatin on serum paraoxonase activity. Clin Drug Invest 21:505-510

Blatter MC, James RW, Messmer S, Barja F, Pometta D (1993) Identification of a distinct human high-density lipoprotein subspecies defined by a lipoprotein-associated protein K-45. Eur J Biochem 211:871-879

Blatter MC, James RW, Dussoix P, Blanche H, Passa P, Froguel P, Ruiz J (1997) Paraoxonase polymorphism Met-Leu 54 is associated with modified concentrations of the enzyme. J Clin Invest 99:62-66

Brophy VH, Jarvik GP, Richter RJ, Rozek LS, Schellenberg GD, Furlong CE (2000) Analysis of paraoxonase (PON1) L55M status requires both genotype and phenotype. Pharmacogenetics 10:453-460

Brophy VH, Jampsa RL, Clendenning JB, McKinstry LA, Jarvik GP, Furlong CE (2001) Effects of $5^{\prime}$ regulatory region polymorphisms on paraoxonase-gene (PON1) expression. Am J Hum Genet 68:1428-1436

Cao H, Girard-Cloba A, Serusclat A, Bernard S, Bondon P, Piicard S, Berthezene F, Moulin P (1998) Lack of association between carotid intima-media thickness and paraoxonase polymorphisms in non-insulin dependent diabetes mellitus. Atherosclerosis 138:361-366

Cao H, Girard-Globa A, Berthezene F, Moulin P (1999) Paraoxonase protection of LDL against peroxidation is independent of its esterase activity towards paraoxon and is unaffected by the Q $\rightarrow$ R genetic polymorphism. J Lipid Res 40:133-139

Datoine TF, Debord J, Charmes JP (1998) Decrease of serum paraoxonase activity in chronic renal failure. J Am Soc Nephrol 9:2082-2088

Davies HG, Richter RJ, Keifer M, Broomfield CA, Sowalla J, Furlong CE (1996) The effect of the human serum paraoxonase polymorphism is reversed with diazoxon, soman and sarin. Nat Genet 14:334-336

Ferre N, Tous M, Paul A, Zamora A, Vendrell JJ, Bardaji A, Camps J, Richart C, Joven J (2002) Paraoxonase Gln-Arg (192) and Leu-Met (55) gene polymorphisms and enzyme activity in a population with a low rate of coronary heart disease. Clin Biochem 35:197-203

Ferretti G, Bacchetti T, Maratti E, Curatola G (2003) Effect of homocysteinylation on human high-density lipoproteins: A correlation with paraoxonase activity. Metabolism 52:146-151

Hegele RA, Brunt JH, Connelly PW (1995) A polymorphism of the paraoxonase gene associated with variation in plasma lipoproteins in a genetic isolate. Arterioscler Thromb Vasc Biol 15:8995 
Herrmann SM, Blanc H, Poirier O, Arveiler D, Luc G, Evans A, Marques-Vidal P, Bard JM, Cambien F (1996) The Gln/Arg polymorphism of human paraoxonase (PON192) is not related to myocardial infarction in the ECTIM study. Atherosclerosis 126:299-303

Humbert R, Alder DA, Disteche CM, Hassett C, Omiecinski CJ, Furlong CE (1993) The molecular basis of the human serum paraoxonase activity polymorphism. Nat Genet 3:73-76

Ikeda Y, Suehiro T, Inoue M, Nakauchi Y, Morita T, Arii K, Ito H, Kumon Y, Hashimoto K (1998) Serum paraoxonase activity and its relationship to diabetic complications in patients with non-insulin dependent diabetes mellitus. Metabolism 47:598602

Imai Y, Morita H, Kurihara H, Sugiyama T, Kato N, Ebihara A, Hamada C, Kurihara Y, Shindo T, Oh-hashi Y, Yazaki Y (2000) Evidence for association between paraoxonase gene polymorphisms and atherosclerotic diseases. Atherosclerosis 149:435-442

Jarvik GP, Rozek LS, Brophy VH, Hatsukami TS, Richter RJ, Schellenberg GD, Furlong CE (2000) Paraoxonase (PON1) phenotype is a better predictor of vascular disease than is $\mathrm{PON}_{192}$ or $\mathrm{PON}_{55}$ genotype. Arterioscler Thromb Vasc Biol 20:2441-2447

Leviev I, James RW (2000) Promoter polymorphisms of human paraoxonase PON1 gene and serum paraoxonase activities and concentrations. Arterioscler Thromb Vasc Biol 20:516-521

Leviev I, Negro F, James RW (1997) Two alleles of the human paraoxonase gene produce different amounts of mRNA: an explanation for differences in serum concentrations of paraoxonase associated with the (Leu-Met 54) polymorphism. Arterioscler Thomb Vasc Biol 17:2935-2939

Li WF, Costa LG, Richter RJ, Hagen T, Shih DM, Tward A, Lusis AJ, Furlong CE (2000) Catalytic efficiency determines the invivo efficacy of PON1 for detoxifying organophosphorus compounds. Pharmacogenetics 10:767-779

Mackness MI, Arrol S, Durrington PN (1991a) Paraoxonase prevents accumulation of lipidperoxide in low-density lipoprotein. FEBS Lett 286:152-154

Mackness MI, Harty D, Bhatnagar D, Winocour PH, Arrol S, Ishola M (1991b) Serum paraoxonase activity in familial hypercholesterolaemia and insulin-dependent diabetes mellitus. Atherosclerosis 86:193-199

Mackness MI, Arrol S, Abbott CA, Durrington PN (1993) Protection of low density lipoprotein against oxidative modification by high density lipoprotein associated paraoxonase. Atherosclerosis 104:129-135

Mackness B, Mackness MI, Arrol S, Turkie W, Durrington PN (1997a) Effect of the molecular polymorphisms of human paraoxonase (PON1) on the rate of hydrolysis of paraoxon. $\mathrm{Br}$ J Pharmacol 122:265-268

Mackness MI, Arrol S, Mackness B, Durrington PN (1997b) Alloenzymes of paraoxonase and effectiveness of high-density lipoprotein in protecting low-density lipoprotein against lipid peroxidation. Lancet 349:851-852

Mackness B, Mackness MI, Arrol S, Turkie W, Julier K, Abuasha B, Miller JE, Boulton AJM, Durrington PN (1998a) Serum paraoxonase (PON1) 55 and 192 polymorphism and paraoxonase activity and concentration in non-insulin dependent diabetes mellitus. Atherosclerosis 139:341-349

Mackness B, Mackness MI, Arrol S, Turkie W, Durrington PN (1998b) Effect of the human serum paraoxonase 55 and 192 genetic polymorphisms on the protection by high-density lipoprotein against low-density lipoprotein oxidative modification. FEBS Lett 423:57-60

Mackness B, Durrington PN, McElduff P, Yarnell J, Azam N, Watt M, Mackness MI (2003) Low paraoxonase activity predicts coronary events in the Caerphilly prospective study. Circulation 107:2775-2779

Odawara M, Tachi Y, Yamashita K (1997) Paraoxonase polymorphism (Gln192Arg) is associated with coronary heart disease in Japanese noninsulin-dependent diabetes mellitus. J Clin Endocrinol Metab 82:2257-2260
Ombres D, Pannitteri G, Montali A, Gandeloro A, Seccareccia F, Campagna F, Cantini R, Campa PP, Ricci G, Arca M (1998) The Gln-Arg 192 polymorphism of human paraoxonase gene is not associated with coronary artery disease in Italian patients. Arterioscler Thromb Vasc Biol 18:16111616

Paragh G, Seres I, Balogh Z (1998) The serum paraoxonase activity in patients with chronic renal failure and hyperlipidemia. Nephron 80:166-170

Paragh G, Balagh Z, Seres I, Harangi M, Boda J, Kovacs P (2000) Effect of gemfibrozil on HDL-associated serum paraoxonase activity and lipoprotein profile in patients with hyperlipidaemia. Clin Drug Invest 19:277-282

Richter RJ, Furlong CE (1999) Determination of paraoxonase (PON1) status requires more than genotyping. Pharmacogenetics 9:745-753

Rodrigo L, Mackness B, Durrington PN, Hernandez A, Mackness MI (2001) Hydrolysis of platelet-activating factor by human serum paraoxonase. Biochemistry J 354:1-7

Saha N, Roy AC, Teo SH, Tay JSH, Ratnam SS (1991) Influence of serum paraoxonase polymorphism on serum lipids and lipoproteins. Clin Genet 40:277-282

Sanghera DK, Saha N, Aston CE, Kamboh MI (1997) Genetic polymorphism of paraoxonase and the risk of coronary heart disease. Arterioscler Thromb Vasc Biol 17:1067-1073

Sanghera DK, Saha N, Kamboh MI (1998) The codon 55 polymorphism in the paraoxonase 1 gene is not associated with the risk of coronary heart disease in Asian Indian and Chinese. Atherosclerosis 136:217-223

Serrato M, Marian AJ (1995) A variant of human paraoxonase/ arylesterase (HUMPONA) gene is a risk factor for coronary artery disease. J Clin Invest 96:3005-3008

Suehiro T, Nakamura T, Inoue M, Shiinoki T, Ikeda Y, Kumon Y, Shindo M, Tanaka H, Hashimoto K (2000) A polymorphism upstream from the human paraoxonase (PON1) gene and its association with PON1 expression. Atherosclerosis 150:295-298

Sutherland WHF, Walker RJ, de Jong SA, van Rij AM, Phillips V, Walker HL (1999) Reduced postprandial serum paraoxonase activity after a meal rich in used cooking fat. Arterioscler Thomb Vasc Biol 19:1340-1347

Tomas M, Senti M, Elosua R, Vila J, Sala J, Masia R, Marrugat J (2001) Interaction between the Gln-Arg 192 variants of the paraoxonase gene and oleic acid intake as a determinant of high-density lipoprotein cholesterol and paraoxonase activity. Eur J Pharmacol 432:121-128

Tomas M, Elosua R, Senti M, Molina L, Vila J, Anglada R, Fito M, Covas MI, Marrugat J (2002) Paraoxonase1-192 polymorphism modulates the effects of regular and acute exercise on paraoxonase1 activity. J Lipid Res 43:713-720

Wang X, Fan Z, Huang J, Su S, Yu Q, Zhao J, Hui R, Yao Z, Shen Y, Qiang B, Gu D (2003) Extensive association analysis between polymorphisms of PON gene cluster with coronary heart disease in Chinese Han population. Arterioscler Thromb Vasc Biol 23:328-334

Watson AD, Berliner JA, Hama SY, La Du BN, Faull KF, Fogelman AM (1995) Protective effect of high density lipoprotein associated paraoxonase: inhibition of the biological activity of minimally oxidised low density lipoprotein. J Clin Invest 96:2882-2891

Wheeler JG, Keavney BD, Watkins H, Collins R, Danesh J (2004) Four paraoxonase gene polymorphisms in 11212 cases of coronary heart disease and 12786 controls: meta-analysis of 43 studies. Lancet 363:689-695

Zama T, Murata M, Matsubara Y, Kawano K, Aoki N, Yoshino H, Watanabe G, Ishikawa K, Ikeda Y (1997) A ${ }^{192}$ Arg variant of the human paraoxonase (HUMPONA) gene polymorphism is associated with an increased risk for coronary artery disease in the Japanese. Arterioscler Thromb Vasc Biol 17:35653569 